\title{
DAMPAK PEMBANGUNAN WADUK JATIGEDE TERHADAP KEHIDUPAN SOSIAL BUDAYA MASYARAKATNYA
}

\author{
THE IMPACT OF BUILD JATIGEDE DAM THROUGH SOCIAL AND CULTURAL \\ LIFE OF SOCIETY
}

\author{
Yuzar Purnama \\ Balai Pelestarian Nilai Budaya (BPNB) Bandung \\ Jln. Cinambo No. 136 Ujungberung-Bandung 42094 \\ e-mail: yuzarpurnama@gmail.com
}

\begin{abstract}
Abstrak
Belakang ini mencuat keresahan masyarakat yang terkena dampak pembangunan Waduk Jatigede. Seolah merupakan kasus baru, padahal masalah Waduk Jatigede sudah berlangsung cukup lama yakni sejak presiden Republik Indonesia, Soekarno. Pembangunan Waduk Jatigede adalah proyek pembuatan pembangkit tenaga listrik. Proyek ini berada di wilayah administrasi Kabupaten Sumedang, Provinsi Jawa Barat, meliputi Kecamatan Jatigede, Wado, Cisitu, Darmaraja, dan Kecamatan Jatinunggal. Penelitian ini menarik karena sejak pertama di mulainya pembangunan waduk sampai sekarang, Januari 2015, belum selesai. Penelitian ini mengupas dampak pembangunan Waduk Jatigede terhadap kehidupan sosial budaya masyarakatnya, yang dibatasi pada masalah ganti rugi, relokasi, dan tinggalan nilai budaya. Penelitian bertujuan untuk mengetahui dampak sosial budaya pembangunan waduk terhadap masyarakatnya. Metode penelitian yang digunakan adalah metode kualitatif, metode kajiannya deskriptif analitik. Penelitian di mulai dari sumber pustaka, mencari data lapangan dengan observasi dan wawancara, klasifikasi data, analisis, dan laporan penelitian. Dari penelitian disimpulkan bahwa dampak sosial seperti permasalahan relokasi, ganti rugi, dan masalah tinggalan budaya yang meresahkan warga merupakan imbas dari pembangunan waduk. Permasalahan sebenarnya bisa diminimalisir jika pembangunan tidak tersendat akibat perencanaan kurang matang dan faktor dana. Namun seiring berjalan waktu permasalahan tersebut sedikit demi sedikit dapat ditangani oleh berbagai pihak dan diharapkan tahun 2015 waduk mulai digenangi.
\end{abstract}

Kata kunci: pembangunan, Waduk Jatigede, sosial budaya.

\begin{abstract}
Fidgetiness appear at this moment because of the developing of Jatigede Dam. Apparently as a new case, actually this thing has appeared since the first president of Indonesia, Soekarno. The build of Jatigede Dam is the project of generator of electricity power. This project are in the administraton area of Sumedang Regency, West Java Province. Jatigede project involved of five area in five sub-district, there are; Jatigede, Wado, Cisitu, Darmaja, and Jatinunggal Subdistrict. Not all of the area got the effect, only 26 villages. This research are quite interesting because since the Jatigede Dam were built until the years of 2015 the project is not finished. The first problem is related to the unfinished problems of social and cultural. This research purpose is to reveal the effect of Jatigede Dam for life of social cultural society, which focused on claim damages, relocated, and the legacy of cultural values or customs. The research
\end{abstract}


method is qualitative, and the discussing method is descriptive analytic. The step of the research start from library research, finding the field collection with observation and interview, continued with classification the data, analysis and arranged the research report. From this research can be concluded that social impact such as relocated problems, claim damages, and the legacy of the ancestor as the impact of Jatigede building process. Actually, if the building of Jatigede run smoothly, the problems can be minimize. In line with the time, little by little the problems get solved handled by the authority, in this case are the local government or centre government. And the target to settle up all of the problems in the years 2015.

Keywords: Development, Jatigede Dam, Social-cultural.

\section{A. PENDAHULUAN}

70 tahun sudah Indonesia merdeka. Berapa juta jiwa melayang dan jumlah harta yang tidak terhitung untuk merebut kemerdekaan, membebaskan diri dari kolonialisme Belanda, Jepang, Inggris, dan Portugis. Jutaan nyawa para pahlawan menjadi tumbal kemerdekaan Republik Indonesia yang diproklamasikan pada tanggal 17 Agustus 1945. Mulai saat itu rakyat Indonesia menentukan nasibnya sendiri. Berapa nyawa lagi harus melayang untuk mempertahankan kemerdekaan dari kolonialisme Belanda yang ternyata kembali ingin menjajah Bumi Pertiwi, Indonesia tercinta.

Kemerdekaan adalah momentum awal rakyat Indonesia membangun negerinya sendiri dengan gagasan, tenaga, dan modal sendiri. Pembangunan demi pembangunan gencar dilaksanakan mulai Orde Lama (Orla), Orde Baru (Orba), Orde Reformasi sampai sekarang, mulai dari Presiden Soekarno, Presiden Soeharto, Presiden BJ. Habibi, Presiden Abdurahman Wahid, Presiden Megawati, Presiden Susilo Bambang Yudoyono, dan Presiden Joko Widodo.

Pembangunan Waduk Jatigede sudah mulai dirintis sejak zaman Presiden Soekarno. Presiden pertama Indonesia, namun sampai sekarang pembangunannya belum rampung, masih dalam tahap finishing. Adeng mengatakan bahwa Waduk Jatigede itu adalah terbesar kedua setelah Jatiluhur, termasuk proyek lama dari tahun 1960-an, dan pembebasan lahannya dari tahun 1970-an. Mulai dirintis kembali tahun 2008 dan Kementerian Pekerjaan Umum (PU) menargetkan penyelesaian pembangunannya pada tahun 2014 serta rencananya akan diresmikan pada bulan Februari tahun depan. Informasi terbaru, proyek Waduk Jatigede sudah mencapai $70 \%$ dalam proses pembangunannya (2014:81).

Peneliti merasa tertarik dengan pembangunan Waduk Jatigede ini karena sudah beberapa kali rencana penggenangan akan dilaksanakan, dari tanggal 1 Oktober 2013 kemudian 1 Oktober 2014 belum juga dilaksanakan. Ada beberapa masalah yang menghambat penyelesaian Waduk Jatigede ini yaitu: pembangunan fisik yang belum final dan masalah sosial yang belum teratasi.

Sudah cukup lama masyarakat Objek Terkena Dampak (OTD) Waduk Jatigede resah. Mereka melakukan demontrasi baik di wilayahnya sampai ke dinas terkait seperti Pemda Kabupaten Sumedang, DPRD Kabupaten Sumedang, Pemda Provinsi Jawa Barat, DPRD Provinsi Jawa Barat, ke DPR Pusat dan ke Istana Negara di Jakarta. Mereka menuntut keadilan untuk ganti rugi pembebasan tanah dan bangunan yang terkena pembangunan Waduk Jatigede, mereka menuntut uang panundung, menuntut relokasi yang layak dan jelas, sampai meminta pertanggungjawaban pemerintah tentang bakal musnahnya situs-situs dan adat istiadat yang secara turun temurun diwariskan dari leluhurnya. Menurut informan langkah yang mereka lakukan sampai pada tahap yang relatif ekstrim misalnya pernah mengirim utusan ke Jakarta dengan berjalan kaki, bahkan beberapa masyarakat di antaranya warga Desa Sukakersa siap melawan apabila 
penggenangan terjadi sementara permasalahan sosial yang melilit mereka belum tuntas.

Penelitian akan mengupas dampak negatif atau permasalahan sosial yang muncul dalam pembangunan Waduk Jatigede. Ruang lingkup penelitian ini dibatasi pada permasalahan ganti rugi, uang panundung, relokasi, dan nilai budaya atau adat istiadat tinggalan nenek moyang.

\section{B. METODE PENELITIAN}

Penelitian ini menggunakan metode deskriptif analitik yaitu peneliti yang menggunakan metode kualitatif, setelah menyusun perencanaan penelitian kemudian ke lapangan (field) tidak membawa alat pengumpul data, melainkan langsung melakukan observasi atau pengamatan evidensi-evidensi, sambil mengumpulkan data dan melakukan analisis (Wardi Bachtiar, 1997:61). Adapun metode kajiannya menggunakan metode kualitatif. Istilah penelitian kualitatif menurut Kirk dan Miller (1986:9) pada mulanya bersumber pada pengamatan kualitatif yang dipertentangkan dengan pengamatan kuantitatif. Selanjutnya penelitian kualitatif adalah tradisi tertentu dalam ilmu pengetahuan sosial yang secara fundamental bergantung pada pengamatan manusia dalam kawasannya sendiri dan berhubungan dengan orang-orang tersebut dalam bahasanya dan dalam peristilahannya. Adapun Bogdan (1972:5) mendefinikan bahwa metode kualitatif sebagai prosedur penelitian yang menghasilkan data deskriptif berupa katakata tertulis atau lisan dari orang-orang dan perilaku yang dapat diamati. Lexy J. Moleong mengatakan, pada penelitian kualitatif, teori dibatasi pada pengertian: suatu pernyataan sistematis yang berkaitan dengan seperangkat proposisi yang berasal dari data dan diuji kembali secara empiris (1989:9)

Adapun langkah-langkah dalam penelitian ini sebagai berikut: studi pustaka dilakukan untuk mencari data dan referensi sesuai dengan objek penelitian; studi lapangan dengan observasi atau pengamatan secara langsung dilengkapi dengan data wawancara. Kasnodihardjo mengatakan bahwa untuk sasaran penelitian mengenai perilaku/tindakan dan benda, metode pengamatan adalah metode yang paling tepat. Sementara, metode wawancara tepat untuk sasaran penelitian mengenai pengetahuan (1992:18); pengolahan data lapangan kemudian dianalisis dan dibuat laporan.

Pembangunan adalah proses membangun baik fisik maupun nonfisik dengan tujuan untuk mengubah ke arah situasi yang lebih baik. Pembangunan fisik misalnya pembangunan Waduk Jatigede adapun pembangunan nonfisik misalnya membangun mental pemuda Indonesia. Pembangunan Waduk Jatigede memerlukan ratusan hektar tanah milik masyarakat. Dalam proses ini terkadang menemukan hambatan karena masyarakat merasa berat melepas tanahnya. Y. Wartaya Winangun mengatakan bahwa fungsi dan peran tanah dalam berbagai sektor kehidupan manusia memiliki tiga aspek yang sangat strategis, yaitu aspek ekonomi, politik dan hukum, serta aspek sosial (2004 : 21). Bagi manusia, tanah merupakan hal terpenting bagi hidup dan kehidupannya. Di atas tanah, manusia dapat mencari nafkah seperti bertani, berkebun, dan beternak. Di atas tanah pula manusia membangun rumah sebagai tempat bernaung dan membangun (Sutedi, 2008 : 45).

Bambang Rudito (dalam bunga rampai "Kehidupan Sosial Budaya Masyarakat Sumedang, Muhsin, Mumuh \& Rudito, Bambang, 2014: xviii) mengatakan bahwa pembangunan pada dasarnya adalah usaha untuk mengarahkan perubahan kebudayaan sesuai dengan apa yang dikehendaki oleh pemrakarsa pembangunan tersebut, yang dalam hal ini adalah pemerintah. Salah satu usaha untuk mengarahkan perubahan adalah adanya pembangunan Waduk Jatigede di daerah 
Sumedang. Pembangunan ini nyata-nyata ditujukan untuk pembangunan lingkungan pertanian di daerah Utara dari Provinsi Jawa Barat, seperti di daerah Indramayu dan sekitarnya. Pembangunan waduk pada dasarnya terarah pada perubahan lingkungan alam yang pada gilirannya akan mengubah kebudayaan masyarakatnya. Masyarakat yang tadinya bermata pencaharian bertani sawah dengan lingkungan sawah sebagai pembentuk kebudayaannya akan mengalami perubahan lingkungan menjadi perairan atau danau buatan. Blumer (dalam Bunga Rampai "Kehidupan Sosial Budaya Masyarakat Sumedang", 2014: xiii) memperingatkan bahwa situasi baru mengenalkan pendefinisian kembali masalah-masalah. Pola-pola yang diwujudkan kelompok pada dasarnya tidak ada yang permanen. Tindakan kelompok yang muncul pasti juga dimulai atau berakar pada pilihan individu yang ada di dalamnya. Hubungan keterkaitan seperti keluasan dan keterhubungan melalui jaringan-jaringan yang rumit yang di dalam jaringan tersebut terkandung fungsi antarmasing-masing individu.

\section{HASIL DAN BAHASAN \\ 1. Selayang Pandang Jatigede}

Penelitian ini menyoroti kehidupan masyarakat Jatigede karena merupakan wilayah yang akan terkena dampak langsung pembangunan Waduk Jatigede. Masyarakat Jatigede terdapat di wilayah administrasi Kabupaten Sumedang Provinsi Jawa Barat. Masyarakat Jatigede yang akan terkena dampak pembangunan Waduk ini terdapat di wilayah lima kecamatan di Kabupaten Sumedang yaitu: Kecamatan Jatigede, Kecamatan Wado, Kecamatan Jatinunggal, Kecamatan Darmaraja, dan Kecamatan Cisitu.

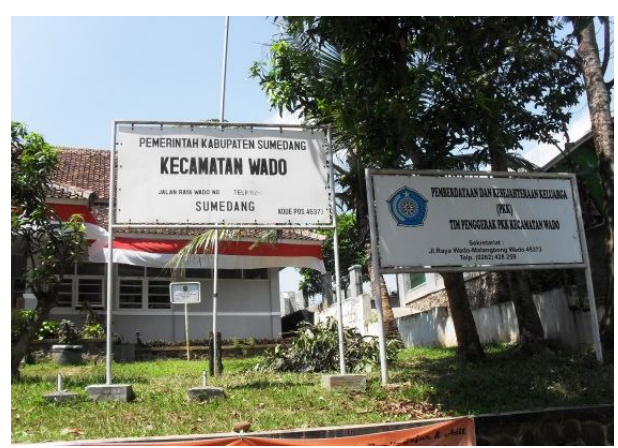

Gambar 1. Kantor Kecamatan Wado Sumber: Dokumentasi BPNB Bandung

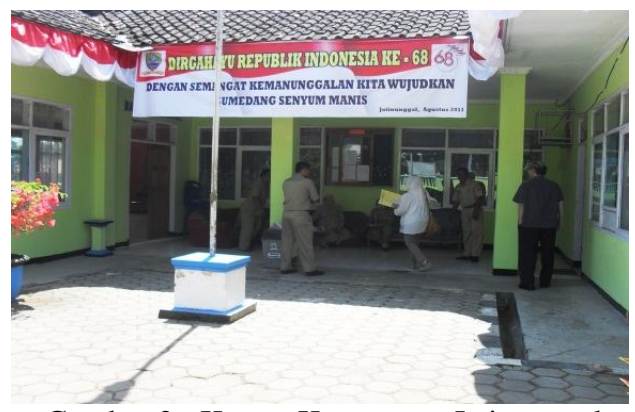

Gambar 2. Kantor Kecamatan Jatinunggal Sumber: Dokumentasi BPNB Bandung

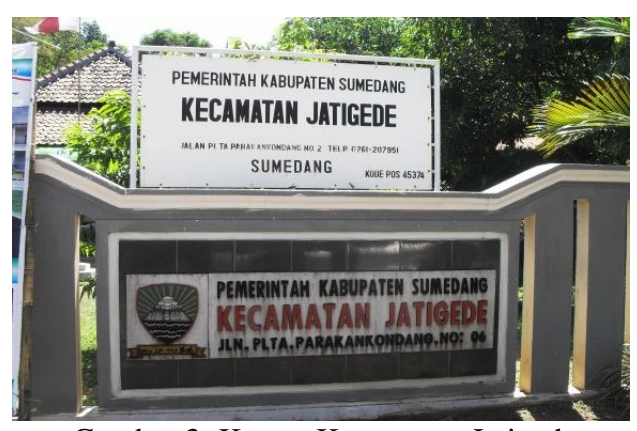

Gambar 3. Kantor Kecamatan Jatigede Sumber: Dokumentasi BPNB Bandung

Dari kelima kecamatan ini tidak semua daratan tenggelam namun ada beberapa desa yang tenggelam. Dengan rincian ada desa yang tenggelam semua seperti Desa Sukakersa dan Desa Padajaya di Kecamatan Jatigede; dan ada desa yang sebagian tenggelam baik pemukimannya maupun kebun dan sawah. 


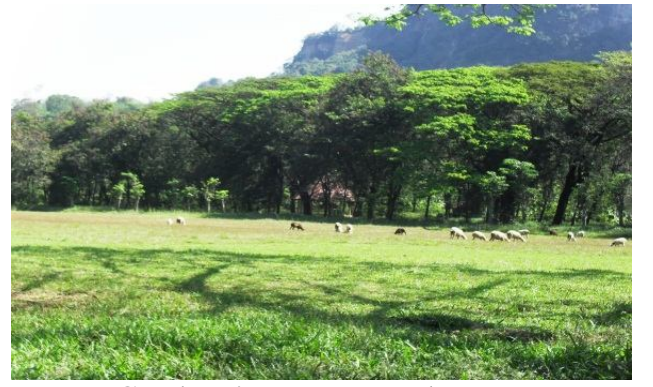

Gambar 4. Kawasan Kabupaten Sumedang yang subur

Sumber: Dokumentasi BPNB Bandung

Secara geografis kelima wilayah yang terkena dampak Waduk Jatigede berada di cekungan yang dikelilingi gunung dan bukit, sehingga layak untuk dijadikan sebuah waduk pembangkit tenaga listrik. Namun demikian, keadaan flora di sekitar ini sangat subur, baik berupa tanaman padi, bakau, pohon jati, maupun pepohonan produktif lainnya seperti mangga, jambu, rambutan, dan sebagainya. Daerah yang subur, hijau, dan ditumbuhi berbagai tanaman produktif sayang jika akhirnya harus hilang karena digenangi air. Sementara itu, dampak pembangunan Waduk Jatigede manfaatnya lebih besar bagi bangsa dan negara, karena dapat meningkatkan jumlah sumber listrik negara untuk penerangan dan pembangunan. Selain itu Waduk Jatigede merupakan pemasok air (irigasi) untuk pertanian di wilayah Pantai Utara (pantura) sekaligus menjadi pengendali banjir.

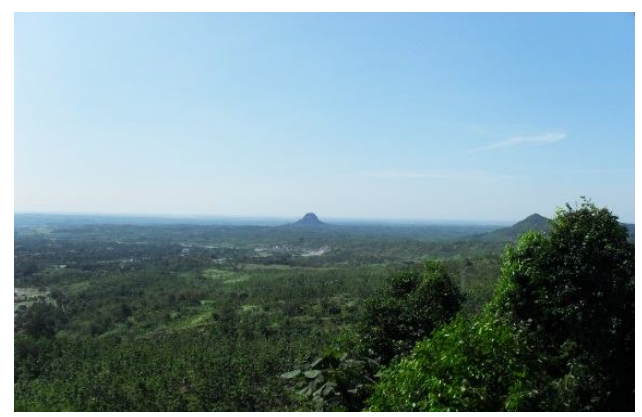

Gambar 5. Kawasan yang Terendam Sumber: Dokumentasi BPNB Bandung

Rencana pembangunan Waduk Jatigede sudah dicanangkan sejak tahun
1960/1961 ketika pemerintahan Republik Indonesia waktu itu dipegang oleh Presiden Ir. Soekarno dan wakilnya Dr. Muhammad Hatta. Studi kelayakan pun sudah dilakukan oleh tim ahli dari Perancis, namun karena pada waktu itu daerah ini dianggap labil dan kemungkinan anggaran yang dibutuhkan pun sangat besar maka pembangunan Waduk Jatigede belum tuntas sampai sekarang dan tampak tersendat-sendat. Sedangkan Waduk Jatiluhur yang studi kelayakannya dilaksanakan setelah Jatigede, ternyata lebih dahulu dibangun menyusul, Waduk Cirata, dan Waduk Saguling.

Realisasi rencana pembangunan Waduk Jatigede dilaksanakan mulai tahun 1970 dan tahun 1982/1983 dengan memberikan ganti rugi kepada masyarakat yang terkena dampak pembangunan Waduk ini secara bertahap. Namun kemudian pembangunan waduk ini terus tersendat-sendat dan tidak nampak untuk segera diselesaikan, sehingga muncul berbagai persoalan yang cukup jelimet.

Sebagian masyarakat yang sudah mendapatkan ganti rugi kemudian ada yang pindah, bertransmigrasi, dan ada pula yang tetap mendiami rumah-rumah di sana untuk menghuni sementara sampai tanahnya mulai digenangi air. Hal tersebut dikuatkan oleh pejabat setempat yang membolehkan mendiami rumah dan menggarap tanahnya seperti sediakala sampai tergenang air waduk. Namun karena penyelesaian pembangunan waduk ini yang tidak kunjung datang, akhirnya masyarakat yang sempat pindah, kembali lagi dan menggarap tanahnya yang dulu ditinggalkan.

Lamanya pembangunan berdampak pada beberapa masyarakat yang dulu menerima uang ganti rugi, banyak yang sudah meninggal. Sementara penerusnya baik anaknya maupun cucunya merasa tidak pernah mendapatkan ganti rugi kemudian sebagian menuntut uang ganti rugi. Persoalan bertambah jelimet dan pelik. Apalagi ada aturan seandainya pembebasan tanah yang sudah dilakukan 
dibiarkan selama 30 tahun, maka ahli waris berhak menuntut ganti rugi baru; artinya perjanjian lama yang sudah 30 tahun dianggap hangus dan tidak berlaku lagi.

Ketika terdengar wacana bahwa waduk Jatigede dianggap tidak ada masalah, semua persoalan sudah selesai, maka pemerintah akan mulai mengairi Waduk pada tanggal 1 Oktober 2013, maka sebagian masyarakat OTD (Objek Terkena Dampak) mulai resah dan gelisah. Berbagai cara dilakukan untuk memperlihatkan kepada pemerintah bahwa persoalan sosial belum tuntas, banyak permasalahan yang belum diselesaikan. Akhirnya gerakan mereka pun sampai dan ditanggapi oleh pemerintah bahwa penggenangan Waduk Jatigede tidak akan dilakukan sebelum persoalan sosial selesai. Adapun penggenangan yang akan dilaksanakan pada bulan Oktober 2013 itu hanya untuk pengujian kalau-kalau ada tempat yang bocor atau rembes. Penggenangannya tidak akan dilakukan secara keseluruhan namun hanya pada titik-titik tertentu untuk melihat bagian yang diperkirakan rawan bocor atau rembes.

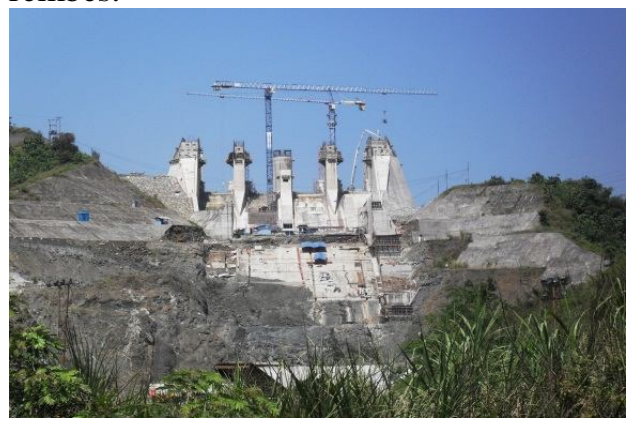

Gambar 6. Bendungan dan Pengendali Air Waduk Jatigede Sumber: Dokumentasi BPNB Bandung

Waduk Jatigede yang dikerjakan oleh kontraktor dari Negeri Cina ini merupakan waduk yang terbesar kedua setelah Waduk Jatiluhur, oleh karena itu dapat dibayangkan berapa banyak kontribusinya untuk pembangunan bangsa dan negara. Dapat diperkirakan jumlah pasokan listrik yang dihasilkan akan lebih baik dan lebih besar jika dibandingkan dengan pasokan listrik yang dihasilkan oleh Waduk Cirata dan Waduk Saguling. Sementara itu, diharapkan pertanian di wilayah Pantai Utara akan lebih baik lagi hasilnya sehingga dapat meningkatkan produksi padi untuk kebutuhan daerah dan nasional.

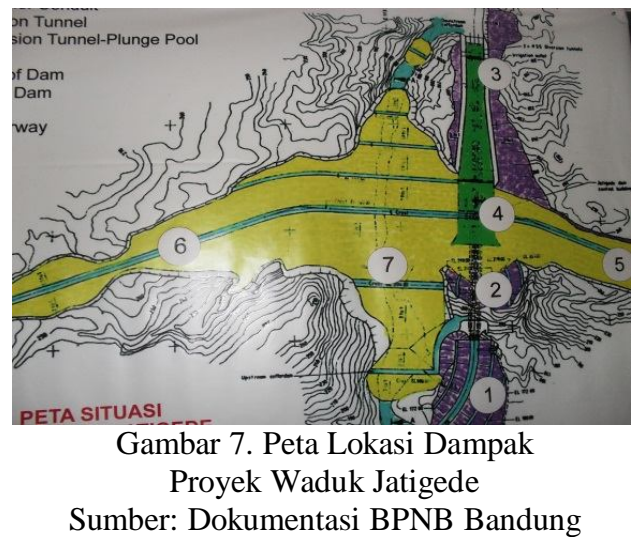

Berdasarkan informasi dari Bapak Kasimin petugas Urusan Tanah dan Penggenangan Satkorlak Departemen Pekerjaan Umum, bahwa daerah-daerah yang akan tergenang sebagai berikut: wilayah yang akan tenggelam adalah Desa Cipaku, Desa Padajaya, dan Desa Cibogo Kecamatan Darmaraja. Daerah atau desa yang akan tenggelam dan akan dihapuskan adalah Desa Leuwiliang dan Desa Sukakersa Kecamatan Jatigede.

Desa-desa yang akan tergenang sebagian adalah Desa Jema Kecamatan Jatigede sebagian besar tergenang; Desa Sukamenak Kecamatan Darmaraja sebagian tergenang; warga Desa Sukamenak ini dulu pernah pindah ke tempat lain namun kembali lagi karena ternyata pembangunan Waduk Jatigede ini tidak kunjung terwujud; Desa Paku Alam Kecamatan Darmaraja tersisa dua kampung yang tidak tergenang, Desa Cisarua, Desa Wado Kecamatan Wado, Desa Ciruas Kecamatan Jatinunggal sebagian tergenang; Desa Pontang Kecamatan Darmaraja dan Desa Ciranggem Kecamatan Jatigede sebagian kecil tergenang; serta Desa Sukaratu 
Kecamatan Darmaraja hanya 2 kampung yang tergenang.

Desa-desa yang hanya tanahnya di luar pemukinan tergenang pembangunan Waduk Jatigede adalah Desa Cijeungjing, Desa Tarmajaya dan Desa Pajagan Kecamatan Jatigede, Desa Sukapura Kecamatan Wado tanahnya sebagian kecil tergenang. Desa Cibitung, Desa Mekar, Desa Cisitu Kecamatan Cisitu dan Desa Cikeusik serta Desa Darmaraja Kecamatan Darmaraja tanahnya tergenang.

\section{Waduk Jatigede}

Dibangunnya Waduk Jatigede berawal dari studi pengembangan wilayah Sungai Cimanuk-Cisanggarung tahun 1963 yang dilaksanakan oleh konsultan Coyne et Bellier dari Perancis. Mereka merekomendasikan perlunya pembangunan Waduk serbaguna untuk mendukung pengembangan wilayah. Pembangunan yang telah dirancang tahun 1963 tersebut, direncanakan akan mengairi 90.000 hektar sawah di Pantai Utara (Pantura) Jawa Barat. Air waduk tersebut dapat membantu pertanian, dari waduk tersebut dapat mengairi pertanian di Majalengka sampai ke Indramayu yang sebagian besar wilayahnya pertanian.

Ternyata tahun 1963 pembangunan waduk tersebut belum bisa direalisasikan karena terhalang dana pembangunan. Dilatari masukan studi pembangunan waduk tersebut, pemerintah berkesimpulan bahwa pembangunan waduk tersebut sangat dibutuhkan untuk kemajuan bangsa dan negara. Akhirnya pada tahun 1975 dikeluarkan peraturan Kementerian Dalam Negeri (Permendagri) yang mengatur tentang dikeluarkannya ganti rugi untuk 4.500 Kepala Keluarga (KK). Dengan dikeluarkannya Permendagri secara perlahan, perizinan mengenai pembebasan lahan pun dikeluarkan. Pada tahun 1981 keluar surat keputusan Gubernur Kepala Daerah Tingkat I Provinsi Jawa Barat yang berisi penerbitan izin pembebasan tanah dan tata cara pengadaan lahan. Kemudian keluar pula SK Bersama Menteri Dalam Negeri dengan Menteri Pekerjaan Umum tertanggal 5 November 1984 tentang Pembangunan Waduk Jatigede. Pada tahun 1986 rencana pembangunan Waduk Jatigede ditindaklanjuti dengan detail design pada tahun 1986 oleh konsultan SMEC dari Australia. Pada tahun 2006 pembangunan Waduk Jatigede dimulai. Bendungan Waduk Jatigede dibangun di Desa Cijeungjing Kecamatan Jatigede. Pembangunan Waduk Jatigede membutuhkan lahan seluas 4.891,13 hektar yang meliputi lima kecamatan yaitu Kecamatan Jatigede, Kecamatan Jatinunggal, Kecamatan Wado, Kecamatan Cisitu, dan Kecamatan Darmaraja. Dari kelima Kecamatan itu hanya 26 desa, itu pun tidak semua desa tenggelam; ada desa yang tenggelam total, sebagian tenggelam, dan hanya sawahnya saja (Lasmiyati, 2014 : 107).

Waduk Jatigede berlokasi di Kecamatan Jatigede, Kabupaten Sumedang, Jawa Barat merupakan bendungan jenis urugan batu (rockfill). Pembangunan waduk ini memiliki luas sekitar 1.766,06 ha. Waduk ini memiliki tinggi $110 \mathrm{~m}-200$ $m$ dengan kapasitas daya tampung air mencapai 980 juta $\mathrm{m}^{3}$. Waduk Jatigede direncanakan dapat mengairi areal irigasi seluas 90.000 ha, menyediakan air bersih bagi Kabupaten Cirebon, Indramayu dan kawasan sekitarnya dengan kapasitas 3.500 liter/detik, serta menyuplai air untuk PLTA yang mampu menghasilkan listrik sebesar $690 \mathrm{GWH}$ per tahun dengan kapasitas terpasang $110 \mathrm{MW}$.

Waduk Jatigede diprediksi merupakan waduk terbesar kedua di Indonesia setelah Waduk Jatiluhur, karena diperkirakan bisa menjamin saluran irigasi hingga 90.000 ha, menghasilkan pasokan listrik sebesar 110 megawatt, dan dapat mengurangi banjir.

Direktur Jenderal Sumber Daya Air Kementerian Pekerjaan Umum, Mochamad Hasan menargetkan penggenangan Waduk Jatigede bisa dimulai pada bulan September tahun 2014. Penggenangan Waduk ini beberapa kali mundur karena masih terkendala belum keluarnya 
keputusan presiden (keppres). Keppres ini, terhambat oleh penolakan masyarakat yang masih menghuni daerah di sekitar Waduk Jatigede. Secara fisik pembangunan Waduk Jatigede hampir selesai, namun masih ada masalah sosial yang belum selesai.

Jika Waduk Jatigede sudah dibangun, maka aliran air dari Cimanuk sudah bisa tertampung. Aliran air yang sebagian melintas ke Indramayu, bisa tertampung di waduk ini. Kepala Bappeda Jawa Barat, Deny Juanda Puradimaja mengatakan bahwa Waduk Jatigede menjadi salah satu solusi penanganan banjir di kawasan pantura (pantai utara) yakni Cirebon dan Indramayu, Provinsi Jawa Barat. Keberadaan waduk ini salah satu fungsinya adalah untuk mengendalikan banjir dengan jangkauan mencapai 1.400 hektar $^{1}$.

Namun di balik itu ada kekhawatiran masyarakat, di antaranya di era pemanasan global yang seharusnya menjaga dan memelihara hutan, yang terjadi sebaliknya yakni 1.200 ha lahan hutan perawan harus dikorbankan. Selain itu dengan dibangunnya Waduk Jatigede, maka dalam proses konstruksi akan menambah getaran dan kerapuhan tanah Priangan Timur. Fase yang paling getir adalah pengusiran 12.000 keluarga atau kurang lebih 50.000 orang dari 5 kecamatan ke tempat lain. Mereka harus meninggalkan lahan subur yang berpotensi untuk menjadi lumbung beras terbaik seJabar. Tanpa dilirik pemerintah pun, warga mengaku tidak pernah gagal panen, dengan kualitas bulir padi yang lebih baik dari produksi tanah Karawang. Lasmiyati menjelaskan bahwa keberhasilan Sumedang dalam mengupayakan swasembada beras tidak terlepas dari adanya bentangan sawah yang menghampar di wilayah tersebut. Namun sayang, pesawahan subur sebagai penghasil padi yang ada di daerah genangan Jatigede termasuk Desa Sukamenak dan Desa Jatibungur

\footnotetext{
${ }^{1}$ Tempo.co. Jakarta. 24 Januari 2014.
}

Kecamatan Darmaraja nantinya akan tenggelam oleh Waduk Jatigede (2014:104).

Tampaknya pembangunan Waduk Jatigede ini tidak bisa dihentikan karena biaya yang dikeluarkan cukup besar dan kepentingan masyarakat luas lebih dominan. Pembangunan Waduk Jatigede selain untuk mengatasi banjir di Pantura, juga dapat menciptakan aset listrik untuk kepentingan nasional.

Djoko Kirmanto, Menteri Pekerjaan Umum menginginkan agar sebelum waduk tersebut diisi air, semua permasalahan yang berkaitan dengan kepentingan masyarakat sudah terselesaikan. Hal ini sesuai dengan harapan warga OTD pembangunan Waduk Jatigede, mereka siap dipindahkan ke lokasi lain. Asalkan, sesuai komitmen sebelumnya, yakni semua permasalahan dampak sosialnya diselesaikan terlebih dahulu, sebelum penggenangan. Mereka mengatakan,

"Kami warga OTD, dari dulu sudah setuju dan mendukung pembangunan Waduk Jatigede sebagai proyek nasional. Namun sayangnya, dukungan kami, tidak dibarengi dengan keseriusan pemerintah dalam menyelesaikan berbagai dampak sosialnya," kata Ketua Perkotdam Jatiber (Perkumpulan Komunikasi Orang Terkena Dampak Jatigede Bersatu), Djaya Albanik. Sebagai bentuk dukungan terhadap pembangunan Waduk Jatigede, warga OTD siap direlokasi ke tempat lain setelah semua persoalan dampak sosialnya diselesaikan oleh pemerintah, yakni Samsat (Satuan Administrasi Manunggal Satu Atap) Penanganan Dampak Sosial dan Lingkungan Pembangunan Waduk Jatigede (PDSLPWJ) Provinsi Jabar dan Satker (Satuan Kerja) proyek Jatigede. "Tapi masalahnya, Samsat sampai sekarang belum juga menyelesaikan dampak sosial tersebut. Rencananya, Minggu depan Sekda Kab. Sumedang sudah mengundang 
kami untuk melakukan rapat koordinasi (rakor) untuk penyelesaian dampak sosial, saat pembebasan lahan tahun 1982-1986. Dampak sosial itu, di antaranya pembayaran ganti rugi pembebasan lahan warga yang terlewat, salah ukur, salah bayar, salah klasifikasi tanah, tanah terisolasi, rumah tumbuh dan relokasi. Hal senada dikatakan Camat Jatigede, Yaya O.K. Ia mengatakan, masyarakat OTD di wilayah Kec. Jatigede pun, siap dipindahkan ke lokasi lain. Dengan catatan, komitmen sebelumnya harus dipenuhi, yakni dampak sosialnya diselesaikan sebelum penggenangan. Jadi, warga kami yang terkena dampak Jatigede, siap dipindahkan, asalkan sesuai komitmen yang disepakati bersama". ${ }^{2}$

\section{Dampak Sosial Budaya}

Pada tahun 1965 Masyarakat Desa Sukamenak dan Desa Jatibungur, umumnya masyarakat Jatigede sudah mengetahui akan adanya pembangunan waduk. Berita tersebut mereka sampaikan kepada anak-anak dan keturunan mereka. Adanya kabar akan ada penggenangan tersebut, pada umumnya mereka mempunyai rasa khawatir bahkan cemas karena harus meninggalkan tanah kelahiran, mata pencaharian, dan belum tahu tujuan kepindahannya ke lokasi yang baru. Kecemasan semakin menjadi ketika dikeluarkannya Peraturan Kementerian Dalam Negeri Nomor 15 Tahun 1975 yang berisi tentang ketentuan-ketentuan mengenai cara pembebasan tanah (Lasmiyati, 2014:111).

Pembangunan Waduk Jatigede berdampak positif dan negatif. Dampak positif sesuai rencana pembangunan waduk ini akan menjadi waduk kedua terbesar di

\footnotetext{
2 https://www.facebook.com/kabarsumedang/ posts/1480185352202544, diakses tanggal 30 Maret 2014.
}

Indonesia setelah Waduk Jatiluhur yang akan menghasilkan tenaga listrik, area peternakan ikan air tawar, area wisata air, pengendali banjir di daerah Pantura, dan dapat meningkatkan pertanian di daerah Pantura. Adapun dampak negatif pembangunan Waduk Jatigede akan mengurangi penghasilan beras khas Sumedang karena area pertanian digenangi air, banyak situs yang terendam, serta hilangnya nilai budaya peninggalan nenek moyang karena Kabupaten Sumedang dapat dikatakan pusat (puser) budaya Sunda.

Dampak pembangunan Waduk Jatigede dirasakan cukup besar, hal tersebut selain dari pembangunannya tersendat-sendat dari kurun waktu 1963 (perencanaan), 1970/1982/1984/1986 pembebasan tanah dan ganti rugi, perintisan kembali pembangunan tahun 2008, baru pada tahun 2013 inilah pembangunan fisik Waduk ini hampir rampung $(70 \%)$. Namun permasalahan sosial atau dampak sosial masih banyak yang perlu diselesaikan. Oleh karena itu Bupati Kabupaten Sumedang menegaskan bahwa penggenangan Waduk Jatigede belum dilaksanakan sampai selesainya permasalahan sosial. Adapun rencana penggenangan yang akan dilaksanakan pada tanggal 1 Oktober 2013 hanya merupakan uji coba untuk mengecek bagian-bagian yang diperkirakan akan terjadi rembesan atau kebocoran dan rencana penggenangan pada 1 Oktober 2014 belum juga dilaksanakan. Jika dibandingkan dengan dampak sosial ketika dilaksana-kannya pembangunan Waduk Jatiluhur, Waduk Cirata, dan Waduk Saguling, maka dampak dari pembangunan Waduk Jatigede ini lebih besar, hal ini dianggap wajar karena wilayah yang akan digenangi cukup besar melingkupi enam wilayah Kecamatan di Kabupaten Sumedang. Merupakan daerah penghasil beras dari Priangan dan memiliki asset budaya Sunda yang sangat bernilai. Jika pembangunan Waduk Jatigede ini rampung maka diperkirakan panjang bibir waduk 
atau keliling waduk mencapai kurang lebih 42 kilometer.

Dampak sosial pembangunan waduk ini bagi masyarakat Jatigede yang muncul ke permukaan di antaranya belum tuntasnya permasalahan ganti rugi, belum siapnya relokasi, belum dipersiapkan perubahan sosial dari masyarakat petani menjadi masyarakat perikanan, dan hilangnya adat istiadat peninggalan budaya nenek moyang. Permasalahan ini akan dibahas satu per satu pada kupasan di bawah ini.

\section{a. Ganti Rugi}

Pembangunan Waduk Jatigede yang penanganannya tersendat dan berlarut-larut mengakibatkan permasalahan panjang yang tidak kunjung selesai. Panjangnya perjalanan penanganan pembangunan dari tahun 1963 sampai sekarang (2014-2015) dari era presiden Soekarno sampai sekarang ke era presiden terpilih 2014, belum tampak akan terselesaikan.

Masalah ganti rugi di proyek pembangunan Waduk Jatigede terdapat dualisme, pertama ada beberapa kelompok masyarakat yang merasa belum menerima ganti rugi pembebasan tanah. Dalam masalah ganti rugi pembebasan tanah pun banyak tipenya. Ada masyarakat yang sama sekali belum menerima ganti rugi sementara ditemukan ada yang telah dua kali menerima ganti rugi. Ada masyarakat yang merasa belum menerima ganti rugi pembebasan tanah karena kemungkinan yang menerima uang ganti rugi itu dulu adalah kakeknya atau bapaknya yang telah meninggal dunia. Ada pula masyarakat yang menuntut ganti rugi secara adil karena dulu ketika menerima ganti rugi mereka merasa ditekan oleh oknum aparat pada era Orde Baru. Misalnya menurut penuturan informan, dulu pembebasan tanah satu bata (per tumbak) oleh oknum dihargai sekitar Rp 5.000,- padahal pada waktu itu harga pasaran Rp 20.000 . Lasmiyati mengatakan bahwa pada tahun 1983-1986 pembebasan tanah dilakukan pada tahun 1983 mengacu pada Peraturan Menteri Dalam Negeri Nomor 15 tahun
1975. Pembebasan tanah tersebut dilakukan di enam desa yaitu Sukakersa dan Jemah (Kecamatan Cadasngampar), Jatibungur, Cipaku, Pakualam, Karangpakuan, Cisurat (Kecamatan Darmaraja), dan Padajaya Kecamatan Wado. Pembebasan tanah didukung oleh Pemda Jabar, Panitia Sembilan, Departemen Pekerjaan Umum dan Bank Dunia. Proses pembebasan tanah berjalan asimetris dimana rakyat dipaksa menerima ganti rugi $\mathrm{Rp} 300$,- sampai $\mathrm{Rp}$ 500,- per meter persegi. Padahal harga tanah di sekitar lokasi tersebut berkisar antara Rp 70.000,- per tumbak. Ganti rugi yang dilakukan oleh PWS Jatigede tersebut, telah tercapai sekitar $80 \%$. Sisanya yaitu sekira $20 \%$ atau hanya beberapa desa lagi (2014:111).

Dalam sebuah proses penyelesaian masalah apa pun masalah akan tampak ricuh dan muncul berbagai permasalahan baru yang harus segera ditangani penyelesaiannya. Belakangan di media massa ketika terjadi penyelesaian ganti rugi ada pemilik tanah yang mengeluh. Katanya ketika proses ganti rugi yang dilakukan oleh aparat desa dilakukan terlebih dahulu pengukuran. Ternyata pengukuran membengkak lebih besar dari luas tanah yang dimilikinya. Tadinya ia berharap ganti ruginya akan bertambah besar dengan pengukuran yang membengkak tersebut. Namun ternyata ketika pembayaran ganti rugi, uang yang diterimanya malah lebih kecil dibandingkan dengan luas tanahnya yang sebenarnya. Masalah-masalah seperti ini sering muncul dalam proses yang berkaitan dengan uang, oleh karena itu perlu adanya pengawasan yang dilakukan oleh pihak lain, yang independen.

Permasalahan ini sampai sekarang belum selesai, oleh karena itu, perlu adanya musyawarah antara pejabat pemerintah yang terkait dengan pelaksana pembangunan Waduk Jatigede dengan masyarakat yang merasa menjadi korban.

Kedua, menurut pihak pemerintah khususnya pihak Satkorlak Departemen Pekerjaan Umum, permasalahan ganti rugi 
ini sudah selesai sejak dulu. Dan ternyata ketika belakangan ini ada orang yang mengklaim belum menerima ganti rugi, ketika dilakukan pembayaran tidak lama kemudian ia digiring ke pengadilan karena penipuan dan sebagainya.

Menurut pihak pemerintah faktor lamanya penggenangan Waduk Jatigede, disebabkan masalah proses ganti rugi lahan milik warga yang tak kunjung selesai. Untuk meminta warga satu suara, sangat sulit. Jadi, ada warga yang meminta untuk ganti rugi dalam bentuk uang. Ada juga, warga yang ingin direlokasi. Negosiasi dan tawar-menawar harga terus berubah. Solusi yang paling tepat adalah turunnya Perpres (peraturan presiden) yang mencantumkan ganti rugi dengan nilai uang dan nilai rupiahnya dicantumkan di Perpres.

Keseriusan pemerintah untuk menyelesaikan salah satu permasalahan sosial yakni ganti rugi mendapatkan perhatian serius dan sedang dalam proses. Direktur Jenderal Sumber Daya Air Kementerian Pekerjaan Umum (Dirjen SDA), Mohamad Hasan, mengatakan bahwa penggenangan Waduk Jatigede hingga saat ini masih belum dapat dilaksanakan karena masih terkendala dengan masalah kependudukan. Masalah yang paling pelik sekarang adalah masalah penduduk. Dari sekitar 7.000 kepala keluarga, sekitar 5.500 kepala keluarga masih harus diberikan ganti rugi karena dipindahkan. Terkait dengan masalah kependudukan tersebut, Hasan menjelaskan bahwa pemerintah kini masih terus membahas dasar hukum tentang pemberian besaran uang ganti rugi. Pemerintah Provinsi Jawa Barat mengusulkan uang ganti rugi yang akan diberikan kepada sekitar 5.500 kepala keluarga itu berjumlah Rp13 juta hingga Rp 29 juta. Bagaimana memberikan semacam besaran untuk dana kerohiman itu harus betul-betul menurut kajian independen yang dilakukan konsultan bersertifikasi Kemenkeu. Ada dua kelompok penduduk yang terlibat dalam pembangunan Waduk Jatigede. Kelompok pertama dikatakan Hasan sudah dibebaskan oleh Permendagri dan mendapatkan hak rumah serta tanah. Yang kedua mereka yang sudah dibebaskan, tapi masih tinggal di situ ${ }^{3}$.

Informasi lain menyebutkan bahwa dalam rapat yang dihadiri Menteri Perekonomian (Menko), Menteri Keuangan, Kementerian Dalam Negeri dan Badan Perencanaan Pembangunan Nasional (Bappenas), untuk membebaskan lahan masyarakat, pemerintah pusat dan Pemerintah Provinsi Jawa Barat sudah menyiapkan anggarannya. Pemerintah pusat, berkewajiban mengganti rumah; sementara Pemerintah Provinsi Jawa Barat memiliki kewajiban membayar ganti rugi lahan, yakni, setiap kepala keluarga memeroleh ganti rugi lahan sebesar Rp 10 juta per kepala keluarga. Lahan yang harus dibebaskan yang dimiliki oleh 4.590 orang, membutuhkan total anggaran provinsi $\mathrm{Rp}$ 45,9 miliar hanya untuk pembebasan lahan. Adapun penyelesaian masalah rumahnya merupakan tanggung jawab Kementrian Perumahan Rakyat (Kemenpera).

Uang ganti rugi langsung diserahkan kepada yang berhak menerimanya yaitu masyarakat OTD. Namun, penyerahan uang harus disertai bimbingan aparat pemerintah kabupaten agar tidak cepat habis. Bangunan rumah yang telah dibongkar dipersilakan dibawa oleh pemiliknya. Sementara itu, pemerintah pusat sudah membangun 678 rumah untuk relokasi warga di lahan milik Pemprov Jabar. Oleh karena, semuanya mendapat ganti rugi uang maka rumah yang sudah dibangun tidak jadi diberikan kepada warga.

Meski Perpres tersebut sudah mengatur mekanisme ganti rugi, program lain yang sudah disusun seperti membangun kampung seni, pemindahan situs, dan pembuatan bendung rentang tetap berjalan. Lalu jika ada lahan yang masih belum terbebaskan akan diganti pemerintah

\footnotetext{
${ }^{3}$ Antara News. Jakarta
} 
dengan harga wajar. Paling tidak yang krusial di masyarakat sudah diselesaikan ${ }^{4}$.

\section{b. Relokasi}

Permasalahan kedua adalah masalah relokasi. Relokasi dapat diartikan sebagai penempatan kembali penduduk atau warga yang harus berpindah tempat karena suatu kegiatan yang lebih penting bagi bangsa dan negara. Masalah relokasi adalah tanggung jawab dari pihak pemerintah untuk memerhatikan warganya yang menjadi korban pembangunan, dalam hal ini adalah pembangunan Waduk Jatigede, Kabupaten Sumedang, Provinsi Jawa Barat.

Relokasi ini tadinya sudah tidak ada masalah alias selesai. Penyelesaian dilakukan ketika pembayaran ganti rugi yang diadakan pada tahun 1984-1985. Pada saat itu para pemilik tanah di tiga kecamatan yaitu Kecamatan Wado, Kecamatan Cadasngampar, dan Kecamatan Darmaraja mengatakan bahwa jika kelak waduk sudah terwujud akan menerima ganti rugi sejumlah uang dan berangkat transmigrasi ke luar Jawa. Setelah mereka mendapat dana, penggantian dan solusi untuk transmigrasi tersebut, masih ada sebagian kecil masyarakat yang bertahan di lokasi tersebut, dan sebagian lagi memilih pindah ke desa-desa lain yang masih berada di Kabupaten Sumedang (Lasmiyati, 2014:112).

Pemerintah sudah menyiapkan tempat untuk OTD di beberapa kecamatan. Rencananya wilayah yang akan dijadikan relokasi terdapat di Kecamatan Jatinunggal, Kecamatan Cisitu, dan Kecamatan Buah Dua. Namun rencana relokasi ini sampai sekarang belum berjalan mulus. Dapat dikatakan masih mentah karena pelaksanaan di lapangan masih jauh dari perkiraan. Misalnya areal relokasi di wilayah Kecamatan Jatinunggal, pihak pemerintah sudah membebaskan tanah, namun tanah tersebut sampai sekarang belum mulai dibangun.

\footnotetext{
${ }^{4}$ republika.co.id, bandung Selasa, 25 Maret 2014, 17:51 WIB
}

Jangankan dibangun, ketika ditanyakan kapan dibangun, yang terjadi adalah saling lempar tanggung jawab antara pihak Departemen Pekerjaan Umum dengan pihak pemerintah daerah. Ketika ditanya, "Berapa meter persegi jatah bagi setiap kepala keluarga $(\mathrm{KK})$ ? Berapa luas area relokasi yang sudah dibebaskan? Berapa banyak rumah yang akan dibangun? Pihak pemerintah kecamatan setempat pun belum mengetahui secara detilnya.

Sementara itu, dari berbagai informasi diketahui bahwa pemerintah pusat sudah membangun 678 rumah untuk relokasi warga di lahan milik Pemprov Jabar. Tentunya jumlah ini masih sangat kurang dibandingkan dengan jumlah KK yang kena dampak pembangunan waduk ini.

Semoga proses relokasi yang belum selesai dan masih tampak mentah oleh pemerintah daerah dan pusat dapat segera diselesaikan dan dituntaskan sehingga proses akhir pembangunan Waduk Jatigede ini dapat terealisir dengan cepat dan tuntas. Diharapkan masyarakat OTD yang harus berpindah ke lokasi baru yang sudah dipersiapkan pemerintah mendapatkan tempat dan kehidupan yang layak. Bahkan di tempat yang baru lebih sehat, nyaman, dan dapat meningkatkan kesejahteraan hidup mereka dibandingkan dengan di tempat yang sudah ditinggalkan.

\section{c. Perubahan Sosial Mata Pencaharian}

Ketika lingkungan alam berubah dari pertanian menjadi sebuah genangan Waduk dalam areal yang luas, maka kemungkinan besar terjadi perubahan aktivitas (Rostiyati, 2014:29).

Dampak sosial lainnya yang tidak kalah pentingnya adalah dampak kepada masyarakat yang mengalami perubahan sosial dari masyarakat pertanian ke masyarakat nelayan. Dampak ini memang harus dipersiapkan karena beralihnya profesi akan mengubah sosial budaya masyarakat setempat. Secara psikologis harus dipersiapkan agar masyarakat tidak stres terhadap perubahan tersebut. 
Masyarakat akan siap menerima perubahan tersebut, sehingga mereka tidak lagi kebingungan apa yang harus mereka lakukan.

Proses perubahan matapencaharian dan dampaknya kepada masyarakat harus dipersiapkan secara matang dan sistematis. Perlu disiapkan mentalitas dan kesiapan lainnya kepada masyarakat sehingga mereka tidak mengalami dampak kaget atau stres terhadap perubahan tersebut. Mereka dapat menghadapi perubahan sosial tersebut dengan baik dan kondusif. Bahkan mereka diharapkan dengan perubahan sosial yang terjadi dapat meningkatkan PAD setempat. Dalam artian diharapkan dari pembangunan Waduk Jatigede ini masyarakat setempat lebih sejahtera dari sebelumnya, bukan sebaliknya yakni pemiskinan.

Beberapa ahli mengemukakan bahwa dampak perubahan sosial dari satu kondisi ke kondisi lain seperti dari masyarakat bertani kepada masyarakat beternak ikan air tawar jangan terlalu dirisaukan, karena pada dasarnya semua orang atau kelompok masyarakat memiliki power atau kekuatan untuk dapat beradaptasi dengan lingkungan tempat mereka tinggal atau lingkungan tempat mereka berada. Hanya tentunya pihak Pemerintah tetap berkewajiban harus menyiapkan atau memberikan tim penyuluh kepada masyarakat, agar masyarakat sudah menyiapkan perubahan sosial tersebut.

\section{d. U ang Panundung}

Uang panundung adalah uang pengusiran atau sama dengan uang pesangon bagi pegawai yang PHK. Uang panundung ini adalah uang yang disediakan oleh pemerintah kepada warga OTD yang tidak berhak mendapatkan ganti rugi dan relokasi.

Penyelesaian proyek pembangunan Waduk Jatigede di Kabupaten Sumedang Jawa Barat sedang dalam proses, karena pemerintah rencananya akan menyediakan anggaran biaya bagi penduduk di sekitar waduk tersebut dalam Anggaran Penda- patan dan Belanja Negara Perubahan (APBNP) 2014.

Adapun besar anggaran yang diusulkan Satuan Administrasi Manunggal Satu Atap (Samsat) tersebut mencapai Rp 700 miliar. Dana tersebut nantinya akan digunakan untuk memindahkan $6.000 \mathrm{KK}$ yang tidak masuk dalam pendataan relokasi pemerintah gelombang pertama pada 1990.

Permasalahan sosial yang terkait relokasi warga bertahan, baru bisa diselesaikan setelah ada keputusan Presiden Susilo Bambang Yudhoyono (SBY) terkait anggaran. Pasalnya, anggaran relokasi warga bertahan belum masuk dalam APBN 2014. Kepala Bapeda Jawa Barat, Deny Juanda mengatakan setidaknya diperlukan Rp 13 juta per KK untuk memindahkan kelompok warga yang tak memiliki hak relokasi sesuai Permendagri 1975. Tercatat ada sekitar 6.000 KK bertahan yang masuk kelompok ini. Jadi usulnya bagi mereka yang tidak punya hak relokasi diberi dana jatah hidup setahun. Kemudian mau pindah kemana terserah, yang penting radius $20 \mathrm{~km}$ dari daerah asal. Kemudian mereka diberi uang pembongkaran, uang transport, dan sewa rumah setahun, kira-kira Rp 13 juta per Kepala Keluarga (KK).

\section{e. Punahnya Puser Budaya Sunda}

Ada satu wacana dari para pejabat, budayawan, seniman, dan tokoh adat Kabupaten Sumedang bahwa Sumedang adalah sebagai Puser Budaya Sunda, hal tersebut bukan sesuatu yang muluk-muluk atau propaganda. Karena kenyataannya masyarakat Sumedang, khususnya yang hidup di pedesaan masih sangat erat dan kental dalam memelihara dan memegang tali karuhun 'jejak leluhur/nenek moyang'.

Dampak dari pembangunan Waduk Jatigede yang menenggelamkan lima Kecamatan di Kabupaten Sumedang dikhawatirkan akan mengurangi atau menghilangkan jejak adat istiadat peninggalan nenek moyang (karuhun) Sunda, karena Sumedang dianggap sebagai salah satu Puser Budaya Sunda. Hilangnya 
budaya daerah merupakan kerugian yang sangat besar bagi bangsa. Karena budaya daerah itu sangat penting bagi bangsa, budaya daerah merupakan jati diri dan identitas bangsa. Hilangnya budaya daerah berkaitan dengan hilangnya pula suatu bangsa.

Masyarakat Jatigede pada umumnya relatif masih kental memegang teguh tali paranti 'adat istiadat peninggalan leluhur' sampai sekarang. Adat istiadat yang sampai sekarang masih dilakukan oleh masyarakat Jatigede mulai dari upacara siklus kehidupan (perkawinan, hamil, kelahiran, khitanan, dan meninggal), upacara pertanian salah satu di antaranya adalah upacara ngarot atau wuku taun, upacara kaliwonan, muharaman, muludan, rajaban, ngaruat anak tunggal, upacara owar, nyuci pusaka, upacara numbal bumi, upacara nurunan, rayagung, ziarah, upacara buku taun, dan lain-lain. Berbagai kesenian khas Sumedang seperti terebang gede, cikuprak, seni tayub, koromong; beluk, seni ajeng, dan tarawangsa, obat-obatan tradisional, naskah-naskah kuno, ungkapan tradisional seperti abong biwir teu diwengku, abong letah teu tulangan (bagaikan lidah tak bertulang); nu burung diangklungan, $n u$ edan dikendangan, nu gelo didogdogan (orang berdusta didengarkan bahkan diiyakan agar lebih ramai berdustanya); ari umur nunggang gunung, angen-angen pecad sawed (usia tua tapi keinginan seperti anak muda); asa kagunturan madu, kaurugan menyan putih (mendapat kebahagiaan sehingga sangat bersuka cita); lain migusti tapi mupusti (bukan menyembah akan tetapi hanya merawat); lain munjung ka batu nyembah ka sagara (bukan mempertuhan batu dan menyembah lautan); nutur catur karuhun (mengikuti kebiasaan atau perkataan karuhun (leluhur); kedah tumut kana parentahna kedah inggis kana laranganana (harus taat kepada perintah-Nya (Allah SWT) dan takut terhadap larangan-Nya; harus menjauhi segala yang diharamkan-Nya; titip diri sangsang badan (meminta perlindungan agar terhindar dari marabahaya); sakedik anu dibaktikeun ageung anu disuhunkeun (sifat manusia pada umumnya sedikit beribadah (usaha) namun banyak keinginan (tuntutan); сирu manik astagina (pusaka dari karuhun /leluhur; saciduh metu saucap nyata (segala ucapannya benar-benar menjadi kenyataan); ulah nuang cau sisina bisi kasingsal (jangan mengambil pisang bagian pinggir, bakal selalu tersisihkan); teu meunang dahar tunggir bisi ditunggirkeun (jangan suka makan bagian daging ekor ayam, takut nantinya tidak dihormati istrinya); ulah calik di lawang bisi nongtot jodo (jangan duduk di pintu nanti susah mendapatkan jodoh); ulah dirumpak barudak bisi cilaka (anak-anak jangan dilanggar nanti mendapatkan malapetaka); ulah diuk dina bangbarung bisi nongtot jodo (jangan duduk di pintu nanti susah mendapatkan jodoh); teu kengeng nuang cau anu ngadempet (tidak boleh makan pisang yang berdempet nanti anaknya kembar siam); ulah diuk di golodok bisi nongtot jodo (jangan duduk dekat pintu nanti susah mendapatkan jodoh).

Selanjutnya permainan tradisional baik yang dimainkan oleh orang dewasa maupun anak kecil seperti permainan galah, bebedugan, beklen, congklak, sapintrong, dom-doman, lolotekan, wakwakung, oray-orayan, balap kaleci, makan kerupuk, mukul aer, tarik tambang, panjat pinang dan panjat bambu, serta menangkap ikan; mantra-mantra, tabu atau pantangan, perhitungan hari baik atau naktu, kekayaan kosa kata dialek Sunda Priangan, alat-alat dan senjata tradisional, dan lain-lain.

Peninggalan nenek moyang (karuhun) ini dikhawatirkan akan berkurang atau hilang sama sekali karena habitatnya atau lingkungan tempat tumbuh dan berkembangnya adat istiadat tersebut hilang, tenggelam bersama air dari Sungai Cimanuk.

Alasan tersebut bukanlah mengada-ada atau fiktif karena rencana penggenangan area Waduk Jatigede tinggal 
menghitung waktu. Namun demikian kekhawatiran tersebut sebenarnya jangan terlalu dibesar-besarkan karena banyak hal yang memungkinkan peninggalan nenek moyang (karuhun) tidak akan punah.

Wilayah Kabupaten Sumedang cukup besar dan pada umumnya setiap wilayah yang berdekatan dengan lokasi penggenangan Waduk Jatigede relatif memiliki kesamaan dalam adat istiadat peninggalan leluhur. Selain itu, masyarakat yang terkena dampak langsung pembangunan Waduk Jatigede yang terpaksa harus berpindah ke tempat lain, pada umumnya tempat tinggal atau lokasi rumah yang baru tidak begitu jauh dari wilayah genangan. Sehingga mereka mempunyai peluang yang cukup besar untuk meneruskan menjalankan adat istiadat peninggalan leluhur di daerah baru dan tentunya masyarakat sekitarnya memiliki persamaan dengan mereka.

Selain itu pihak pemerintah pun tidak tinggal diam dalam masalah ini, terbukti dengan permasalahan yang menyangkut situs-situs yang cukup banyak di area penggenangan, sebagian besar sudah ditangani oleh pemerintah. Penanganan ini berkaitan dengan tanggung jawab pemerintah dalam mengamankan, menja-ga, dan melestarikan peninggalan nenek moyang baik yang bernilai budaya maupun yang bernilai sejarah. Adeng mengatakan bahwa situs-situs yang akan tenggelam itu sebanyak 46 situs yang lokasinya di Kecamatan Darmaraja, Wado, dan Jatigede. Situs-situs itu sebagian peninggalan masa prasejarah, masa Kerajaan Tembong Agung atau Sumedanglarang, dan sebagian lagi makam leluhur pendiri desa (2014:81).

Selain adanya potensi personal dalam mempertahankan, melestarikan dan melindungi peninggalan nenek moyang (leluhur) seperti diulas di atas, upaya lainnya adalah dengan membuat sebuah lingkungan seni atau komunitas seni yang di dalamnya berupaya menjalankan dan mempertahankan adat istiadat leluhur. Upaya ini sedang diusahakan baik oleh pemerintah maupun swasta juga pihak masyarakat yang terus berjuang untuk mendapatkan dukungan moril dan spiritual.

Masyarakat yang berkeinginan terwujudnya komunitas kampung seni di wilayah penampungan korban pembangunan Waduk Jatigede tampaknya sangat membutuhkan bantuan moril alias dana dari berbagai pihak. Namun bantuan tampaknya masih jauh dari harapan karena proses penggenangan saja belum dimulai.

\section{PEN UTU P}

Pembangunan adalah kegiatan yang mustahil dapat dihindarkan dalam peta kehidupan masyarakat manusia. Sebesar atau sekecil apa pun riak pembangunan pasti akan dilakukan oleh manusia. Karena pembangunan bertujuan untuk mengubah suatu kondisi menjadi lebih baik dari sebelumnya.

Pembangunan ini mencakup pembangunan fisik dan non-fisik. Pembangunan fisik mencakup pembangunan yang dapat dilihat secara kasat mata misalnya membuat gedung, membuat jalan, membuat waduk pembangkit listrik, dan lainlain, adapun pembangunan non-fisik mencakup pembangunan mental manusia.

Perbuatan atau sebuah tindakan akan menanggung risiko atau akan ada dampak yang menyertainya, begitu pula dalam pembangunan Waduk Jatigede. Pembangunan ini berdampak positif maupun negatif. Dampak yang disoroti dalam penelitian ini adalah dampak negatif dari pembangunan waduk ini yaitu permasalahan sosial.

Permasalahan sosial yang terdapat dalam pembangunan Waduk Jatigede sangat pelik dan rumit, hal ini disebabkan oleh lama waktu antara pembangunan, namun demikian berbagai elemen terus mengusahakan penyelesaian permasalahan sosial ini. Masalah ganti rugi, masalah relokasi, masalah uang panundung, masalah perubahan sosial dari masyarakat bertani ke masyarakat beternak ikan air tawar terus ditangani dan diselesaikan oleh pemerintah, masyarakat, pihak swasta, dan elemen masyarakat lainnya. Upaya ini 
ditempuh untuk melancarkan dan memuluskan penyelesaian pembangunan Waduk Jatigede agar manfaatnya segera dirasakan oleh masyarakat banyak.

\section{DAFTAR SUMBER}

\section{Buku}

Adeng. 2014.

Dampak Pembangunan Waduk Jatigede terhadap Peninggalan Sejarah dan Budaya. Bandung: Mawar Putra Perdana.

Adrian Sutedi. 2008.

Implementasi Prinsip Kepentingan Umum dalam Pengadaan Tanah untuk Umum. Sunan Grafika.

Bachtiar,. Wardi. 1997.

Metode Penelitian Ilmu Dakwah. Pamulang Timur Ciputat: Logos Wacana Ilmu.

Bogdan, Robert C. 1972

Participant Oberservation in Organizational Settings, Syracuse. New York.: Syracuse Univercity Press.

Kasnodihardjo. 1992.

Lebih Jauh Mengenal Metode Pengamatan (Makalah). Puslit Ekologi Kesehatan Badan Litbangkes.

Kirk, Jerome \& Marc L. Miller. 1986

Realibility and Validity in Qualitative Research. New York: St. Martin Press.

Lasmiyati. 2014.

Dampak Pembangunan Waduk Jatigede terhadap Masyarakat Petani di Desa Sukamenak dan Jatibungur. Bandung : Mawar Putra Perdana.

Muhsin, Mumuh \& Rudito, Bambang. 2014. Bunga Rampai Kehidupan Sosial Budaya Masyarakat Sumedang. Bandung: Mawar Putra Perdana.

Moleong, Lexy J. 1989.

Metodologi Penelitian Kualitatif. Bandung : Remaja Karya.

Rostiyati, Ani. 2014.

Upacara Tradisional pada Masyarakat Tradisional Jatigede
Kabupaten Sumedang. Bandung: Mawar Putra Perdana.

Winangun, Y. Wartaya. 2004.

Tanah Sumber Nilai Hidup. Cetakan

1. Yogyakarta : Kanisius.

\section{Internet}

https://www.facebook.com/kabarsumedang/ posts/1480185352202544, diakses tanggal 30 Maret 2014. 